\title{
Theoretical transition probabilities, oscillator strengths, and radiative lifetimes of levels in $\mathrm{Pb} \mathrm{IV}$
}

\author{
A. Alonso-Medina ${ }^{a}$, C. Colón ${ }^{a, *}$, P. Porcher ${ }^{b}$ \\ ${ }^{a}$ Dpto. Física Aplicada. E.U.I.T. Industrial, Universidad Politécnica de Madrid, Ronda de Valencia 3, 28012 Madrid, Spain \\ ${ }^{\mathrm{b}}$ Laboratoire de Chimie Appliquée de l'Etat Solide, CNRS-UMR 7574 Paris, France
}

\section{A B S T R A C T}

Transition probabilities and oscillator strengths of 176 spectral lines with astrophysical interest arising from $5 \mathrm{~d}^{10} n \mathrm{~s}(n=7,8), 5 \mathrm{~d}^{10} n \mathrm{p}(n=6,7), 5 \mathrm{~d}^{10} n \mathrm{~d}(n=6,7), 5 \mathrm{~d}^{10} 5 \mathrm{f}, 5 \mathrm{~d}^{10} 5 \mathrm{~g}, 5 \mathrm{~d}^{10} n \mathrm{~h}(n=6,7,8), 5 \mathrm{~d}^{9} 6 \mathrm{~s}^{2}$, and $5 d^{9} 6 s 6 p$ configurations, and radiative lifetimes for 43 levels of $\mathrm{Pb}$ IV, have been calculated. These values were obtained in intermediate coupling (IC) and using relativistic Hartree-Fock calculations including core-polarization effects. For the IC calculations, we use the standard method of least-square fitting from experimental energy levels by means of the Cowan computer code. The inclusion in these calculations of the $5 d^{10} 7 \mathrm{p}$ and $5 \mathrm{~d}^{10} 5 \mathrm{f}$ configurations has facilitated a complete assignment of the energy levels in the $\mathrm{Pb}$ IV. Transition probabilities, oscillator strengths, and radiative lifetimes obtained are generally in good agreement with the experimental data. 


\section{Contents}

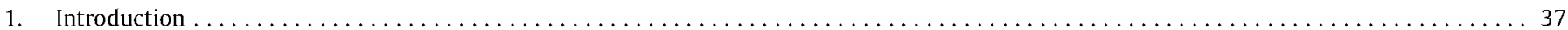

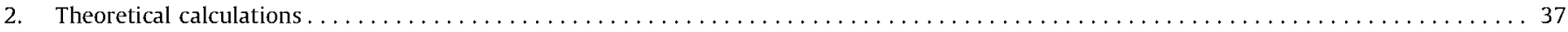

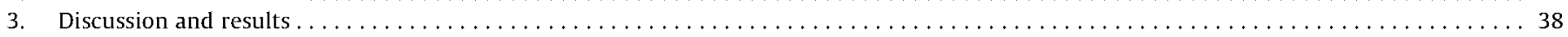

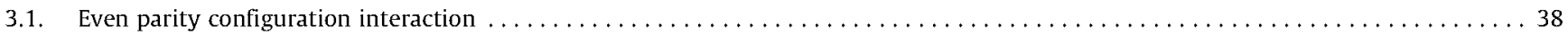

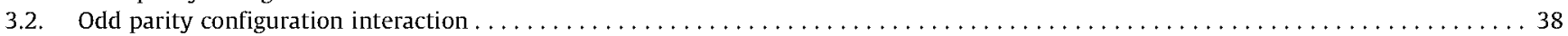

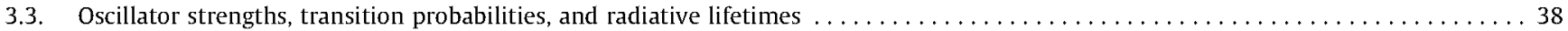

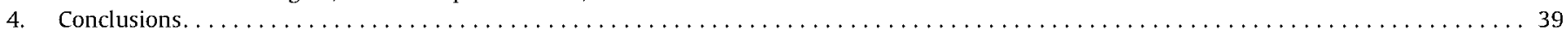

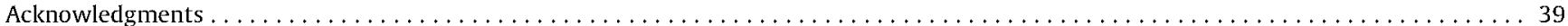

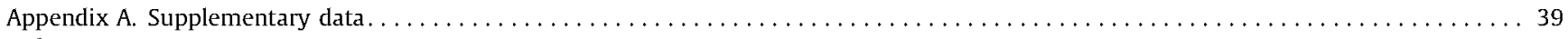

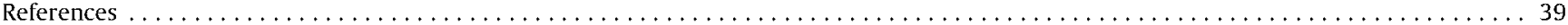

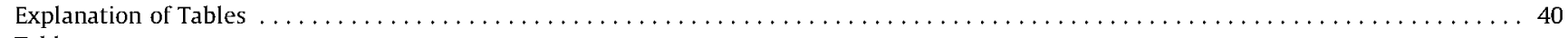
Tables

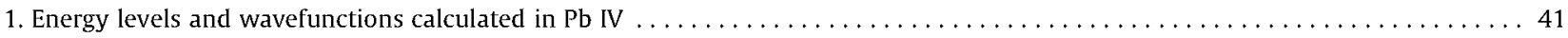

2. Parameters resulting from the least-square fitting of the intermediate coupling calculations ...................43

3. Oscillator strengths and transition probabilities of spectral lines arising from $5 \mathrm{~d}^{10} n$ s configurations and radiative lifetimes of $\mathrm{Pb}$ IV... 44

4. Oscillator strengths and transition probabilities of spectral lines arising from $5 d^{10} 6 \mathrm{p}$ and $5 d^{9} 6$ s6p configurations and radiative lifetimes of

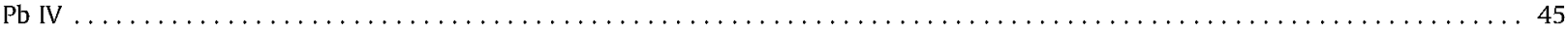

5. Oscillator strengths and transition probabilities of spectral lines arising from $5 \mathrm{~d}^{10} \mathrm{nd}$ configuration and radiative lifetimes of Pb IV.... 47

6. Oscillator strengths and transition probabilities of spectral lines arising from $5 \mathrm{~d}^{10} 5 \mathrm{~g}$ and $5 \mathrm{~d}^{10} \mathrm{nh}$ configurations and radiative lifetimes of

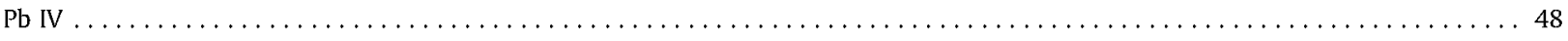
Graph

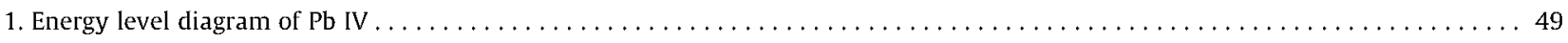

\section{Introduction}

Data on atomic properties are not only relevant to spectroscopy, but are of interest in a variety of other fields in physics and technology. In astrophysical applications, information about the transition probabilities and lifetimes can be used to determine elemental abundances from absorption spectra. These data are also essential to calculate the Stark width and shift parameters of spectral lines. Recent observations with the Hubble Space Telescope have raised the need of accurate radiative parameters for heavy atoms in different ionization states. In particular the presence of $\mathrm{Pb}$ IV in stellar spectra have been reported in a few different types of stars. Proffitt et al. [1] in 2001 determined the lead abundance of the early B main-sequence star AV 304 in the Small Magallanic Cloud by measuring the $1313.1 \AA$ resonance line of $\mathrm{Pb}$ IV. Resonance lines of $\mathrm{Pb}$ IV has been detected in Far Ultraviolet Spectroscopic Explorer spectra of hot subdwarf B stars by Chayer et al. [2] and O'Toole [3].

Some theoretical oscillator strengths for $\mathrm{Pb}$ IV were the subject of a previous work carried out by the present authors [4]. In this previous work we used relativistic Hartree-Fock (HFR) calculations to obtain the oscillator strengths, but no core-polarization effects were included in these calculations. The $\mathrm{Pb}$ IV spectrum was studied earlier in the range from 200 to $9000 \AA$ by Schoepfle [5] and Crawford et al. [6]. Analyses of transitions from the autoionizing states $5 d^{9} 6 \mathrm{~s} n \mathrm{f}(n=5,6,7)$ to the $5 \mathrm{~d}^{10} 6 \mathrm{~s}^{2} \mathrm{~S}_{1 / 2}$ in $\mathrm{Pb}$ IV have also been reported $[7,8]$. Measurements of oscillator strengths of $\mathrm{Pb}$ IV were reported by Tkukhan et al. [9]. Relativistic single configuration Hartree-Fock calculations including core-polarization effects only for the $\mathrm{p}-\mathrm{s}$ and $\mathrm{d}-\mathrm{p}$ transitions were made by Migdalek et al. [10]. Also, Dirac-Fock (DF) calculations were made by Migdalek et al. [11]. Relativistic many-body calculations for levels of $\mathrm{Pb}$ IV were made by Chou et al. [12]. Excitation energies, oscillator strengths, and lifetimes were reported by Safronova et al. [13].

In addition, Andersen et al. [14] presented a beam- foil study of atomic lifetimes showing the spectral line at $1028.6 \AA$ of $\mathrm{Pb}$ IV. The beam-foil technique was used by Pinnington et al. [15] to obtain lifetimes of the $5 d^{10} 5 f, 5 d^{10} 5 g, 5 d^{10} 6 d, 5 d^{10} 6 h, 5 d^{10} 7 p, 5 d^{10} 7 d$, $5 \mathrm{~d}^{10} 8 \mathrm{~s}$, and $5 \mathrm{~d}^{9} 6 \mathrm{~s} 6 \mathrm{p}\left[2^{\circ}\right],\left[3^{\circ}\right],\left[6^{\circ}\right],\left[14^{\circ}\right],\left[17^{\circ}\right]$, levels of Pb IV. In the same way, lifetimes of the $5 \mathrm{~d}^{10} 6 \mathrm{p}, 5 \mathrm{~d}^{10} 6 \mathrm{~d}, 5 \mathrm{~d}^{10} 7 \mathrm{~s}$, and $5 \mathrm{~d}^{9} 6 \mathrm{~s}^{2}$ levels were measured by Ansbacher et al. [16].
In the present work we tabulate transition probabilities and oscillator strengths of 176 spectral lines arising from $5 \mathrm{~d}^{10} n \mathrm{~s}$ $(n=7,8), 5 \mathrm{~d}^{10} n \mathrm{p}(n=6,7), 5 \mathrm{~d}^{10} n \mathrm{~d}(n=6,7), 5 \mathrm{~d}^{10} 5 \mathrm{f}, 5 \mathrm{~d}^{10} 5 \mathrm{~g}, 5 \mathrm{~d}^{10} n \mathrm{~h}$ $(n=6,7,8), 5 d^{9} 6 s^{2}$, and $5 d^{9} 6 s 6 p$ configurations and radiative lifetimes of 43 levels of $\mathrm{Pb}$ IV. Some of these lines are in the ultraviolet range (e.g., 1313.1 and $1328.6 \AA$ ) with astrophysical relevance $[2,3]$. For other lines there are neither theoretical nor experimental results published. A comparison between theoretical lifetimes deduced from our calculations and the experimental values available in the literature is also presented. This work complements the study of the experimental configurations of the $\mathrm{Pb}$ IV by Moore [17].

The system considered is complex; for high $Z$ both relativistic and correlation effects could be relevant. The values were calculated in the framework of the HFR by means of the Cowan computer code [18] in which we have incorporated the core-polarization (CP) effects by means of a potential model and a correction to the electric dipole operator.

This work widens the previous work [4], providing a complete set of $\mathrm{Pb}$ IV oscillator strengths for observed levels. We describe in Section 2 the theoretical calculations, in Section 3 the discussion and the results, and the conclusions are presented in Section 4 .

\section{Theoretical calculations}

Relativistic single configuration Hartree-Fock oscillator strengths for the lowest $n \mathrm{p}{ }^{2} \mathrm{P}_{1 / 2,3 / 2^{-}} n \mathrm{~s}^{2} \mathrm{~S}_{1 / 2}$ and $n \mathrm{~d}^{2} \mathrm{D}_{3 / 2,5 / 2}-n \mathrm{p}$ ${ }^{2} \mathrm{P}_{1 / 2,3 / 2}$ transitions in $\mathrm{Pb}$ IV including core-polarization effects were made by Migdalek et al. [10]. In a later work these same transitions were calculated using a DF model including core-polarization effects. Excitation energies, oscillator strengths, and lifetimes for $n s_{1 / 2}(n=6,9), n p_{j}(n=6,8), n d_{j}(n=6,7)$ and $5 f_{j}$ states in Pb IV were calculated by Safronova et al. [13] using relativistic many-body perturbation theory.

In the present work, in order to provide a complete set of transitions probabilities and the corresponding oscillator strengths, HFR and configuration interaction calculations were made using Cowan's programs [18]. The basis set used in this work consists of seven configurations of even parity, namely, $5 \mathrm{~d}^{10} n s(n=6-8)$, $5 d^{10} n d(n=67)$ and $5 d^{10} 5 g$ and $5 d^{9} 6 s^{2}$ and seven configurations of odd parity, namely, $5 \mathrm{~d}^{10} n \mathrm{p}(n=67), 5 \mathrm{~d}^{10} 5 \mathrm{f}, 5 \mathrm{~d}^{10} n \mathrm{~h}(n=6-8)$ and $5 d^{9} 6 s 6 p$. 
For the intermediate coupling (IC) calculations, we used the standard method of least-square fitting of experimental energy levels by means of the computer programs of Cowan [18]. For the calculations, we used all the experimental levels $(11+34$ levels) shown in the Moore table.

Due to the high number of parameters to adjust (that exceeds the number of experimental levels) we have excluded the adjustment process for a certain number of parameters. We take for all the $F^{k}, G^{k}$, and $R^{k}$ integrals not adjusted in the fitting procedure the $a b$ initio HFR values scaled down by a factor of 0.85 (as suggested by Cowan). For the spin-orbit integrals $\zeta_{n i}$ characterized by small numerical values and not adjusted in the fitting procedures we used the $a b$ initio HFR values without scaling. All the details of the fitting procedure are not given here but can be obtained upon request from the authors. Results of the process for the configuration interactions $5 \mathrm{~d}^{9} 6 \mathrm{~s} 6 \mathrm{p}, 5 \mathrm{~d}^{10} 7 \mathrm{p}$, and $5 \mathrm{~d}^{10} 5 \mathrm{f}$ levels are shown in Tables 1 and 2 .

In the same way as our previous work for Pb III [19], we have included the $\mathrm{CP}$ effects. These effects are included following the suggestions of Migdalek et al. [20]; they can be written as one-particle, $V_{P 1}$, and two-particle, $V_{P 2}$, potential models,

$V_{P 1}=-\frac{1}{2} \alpha_{\mathrm{d}} \sum_{i=1}^{n} \frac{r_{i}^{2}}{\left(r_{i}^{2}+r_{c}^{2}\right)^{3}}$

and

$V_{P 2}=-\alpha_{\mathrm{d}} \sum_{i>j}^{n} \frac{\vec{r}_{i} \cdot \vec{r}_{j}}{\left[\left(r_{i}^{2}+r_{c}^{2}\right)\left(r_{j}^{2}+r_{c}^{2}\right)\right]^{3 / 2}}$

where $\alpha_{d}$ is the dipole polarizability of the core and $r_{c}$ is the cut-off radius chosen as a measure of the size of the ionic core.

A modification in the radial matrix element can be made in order to take into account the potential change. The matrix element $\left\langle P_{n l}|r| P_{n^{\prime} l^{\prime}}\right\rangle$ is replaced by

$\int_{0}^{\infty} P_{n l} r\left(1-\frac{\alpha_{d}}{\left(r^{2}+r_{c}^{2}\right)^{3 / 2}}\right) P_{n l l} d r-\frac{\alpha_{d}}{r_{c}^{3}} \int_{0}^{r_{c}} P_{n l}(r) r P_{n l l}(r) d r$

where the core penetration term suggested by Hameed [21] has also been included. For the dipole polarizability and the cut-off radius we use the values, $\alpha_{d}=3.986$ (in atomic units, a.u.) and $r_{c}=1.268$ (in a.u.), computed by Fraga et al. [22].

In this way we obtained the $L S$ composition of each level and the degree of configuration mixing considering their interactions. For the HFR calculations, the Cowan code provides the radial parts for determining the transition probabilities and initial estimation of the parameters for the IC fittings.

The wavefunctions obtained in this description have been used in this work to obtain the matrix elements and the transition probabilities reported. The transition probabilities and the oscillator strengths are obtained from the matrix elements by using the standard expressions of Martin and Wiese [23]

$A_{k i}=\frac{2 \pi e^{2}}{m_{e} C \varepsilon_{0} \lambda^{2}} \frac{g_{i}}{g_{k}} f_{i k}=\frac{16 \pi^{3}}{3 h \varepsilon_{0} \lambda^{3} g_{k}}\left|<P_{k}\right| \overrightarrow{\mathrm{r}}\left|P_{\mathbf{i}}>\right|^{2}$

where $A_{i j}$ and $f_{i j}$ are the transition probability and the oscillator strength respectively, $e$ and $m_{e}$ are the electron charge and electron mass, $\lambda$ is the transition wavelength, $c$ is the light speed, $h$ is the Planck constant, $g_{k}$ and $g_{i}$ are the statistical weights and $\left\langle P_{k}|\overrightarrow{\mathrm{r}}| P_{\mathrm{i}}\right\rangle$ is the calculated matrix element including the modification pointed out above. The lifetime of a level is the inverse of the sum of the transition probabilities arising from this level. The Lande factors are calculated using the standard expressions given by Cowan [18].
Graph 1 displays a Grotrian scheme of the Pb IV energy levels. Oscillator strengths and transition probabilities corresponding to some spectral lines have been calculated in this work for the first time.

\section{Discussion and results}

\subsection{Even parity configuration interaction}

A comparison between our calculated energy levels and the experimental values [17] show excellent agreement. Also we have found a remarkable agreement between the calculated Lande factors and the experimental values obtained by Green et al. [24]. For the levels $5 \mathrm{~d}^{10} 7 \mathrm{~s}^{2} \mathrm{~S}_{1 / 2}, 5 \mathrm{~d}^{10} 6 \mathrm{~d}^{2} \mathrm{D}_{3 / 2}$, and $5 \mathrm{~d}^{10} 6 \mathrm{~d}^{2} \mathrm{D}_{5 / 2}$ we have obtained values of $2.00,0.80$, and 1.20 , respectively, in comparison with the experimental Lande factors $1.92,0.78$, and 1.17 .

\subsection{Odd parity configuration interaction}

In Table 1 we present the wavefunctions of levels corresponding to the $5 d^{9} 6 s 6$ p configuration in terms of the $L S$ functions and a comparison between experimental and theoretical energy values. Also, the calculated and experimental Lande factors are displayed. There are notable discrepancies in the energies of some levels. We think that these discrepancies are due to the configurations mixing with other excited configurations, not included in this work, without available experimental levels. In order to correct the discrepancies, we made attempts to carry out least-square fitting including some configurations without available experimental levels. This procedure, which presents difficulties due to the increase in the numbers of parameters above the number of experimentally observed energy levels, resulted in no reasonable improvement of our original results.

As can be seen in Table 1, the energy levels of 209788.4 and $217851.9 \mathrm{~cm}^{-1}$ (designated in the column of authors as the Moore tables levels $\left[16^{\circ}\right]$ and $\left[22^{\circ}\right]$ ) can be identified as $5 \mathrm{~d}^{10} 7 \mathrm{p}^{2} \mathrm{P}_{1 / 2}$ and $5 d^{10} 7 p{ }^{2} P_{3 / 2}$, respectively. In the same way, levels 219461.0 and $221716.1 \mathrm{~cm}^{-1}\left(\left[23^{\circ}\right]\right.$ and $\left[24^{\circ}\right]$ in the Moore tables) correspond to $5 d^{10} 5 f^{2} F_{5 / 2}$ and $5 d^{10} 5 f^{2} F_{7 / 2}$.

The values found for the different parameters involved in the IC calculations, compared with the HFR values (used as a start in the fitting process), are shown in Table 2 . The differences between the sets of parameters indicate the existence of configuration interaction perturbations that have been neglected in the calculation. However, in spite of these differences, the parameters obtained are close enough to the $a b$ initio parameters; they maintain their physical meaning, they allow the best adjustment possible of the energy levels calculated at the experimental energy levels, and they provide an appropriate set of transition probabilities and lifetimes. As we have indicated, seeking to improve this adjustment with other configurations was fruitless.

\subsection{Oscillator strengths, transition probabilities, and radiative lifetimes}

Theoretical transition probabilities obtained for 176 lines of $\mathrm{Pb}$ IV with wavelengths in the range from 400 to $8000 \AA$ are displayed in column three of Tables 3-6, while column two gives the corresponding wavelengths. In column four of Tables 3-5, and 6 we present the corresponding oscillator strengths and theoretical values from other authors. In the remaining columns we display the lifetimes calculated in this work and the experimental values taken from the literature. Values presented in these tables are in good agreement with the published experimental ones, but some differences exist among the experimental lifetimes measured by other authors and our calculations. 
In Tables 3 and 5 the calculated lifetimes are within the uncertainties of the experimental measurements. In Table 4 the values of the calculated lifetimes differ around 15\% from the experimental values with the exception of the calculated lifetime of $5 \mathrm{~d}^{9} 6 \mathrm{~s} 6 \mathrm{p}\left[5^{\circ}\right]_{3 / 2}$. In this case the calculated value is 3.9 ns compared with $6.6 \pm 0.3$ ns. A similar situation can be seen in Table 6 . The values of the calculated lifetimes differ around $15 \%$ from the experimental values with the exception of the calculated lifetime of the $5 \mathrm{~d}^{10} 6 \mathrm{~h}$ level which differs $25 \%$ from the experimental value.

\section{Conclusions}

In this paper, we have presented a set of transition probabilities, oscillator strengths, and lifetimes of $\mathrm{Pb}$ IV configurations of astrophysical interest. Core polarization effects are included in our calculations. This inclusion represents an improvement of our previous work and it has allowed us to obtain appropriate values for the lifetimes. In this way we have found a remarkably good agreement between our results and the scarce experimental values. Several of those values calculated are published for the first time in this work. Our calculations confirm the suggestions of Schoepfle [5] that the levels labelled $\left[16^{\circ}\right],\left[22^{\circ}\right],\left[23^{\circ}\right]$, and $\left[24^{\circ}\right]$ may be $5 d^{10} 7 p^{2} \mathrm{P}_{1 / 2.3 / 2}$ and $5 d^{10} 5 f^{2} \mathrm{~F}_{5 / 2.7 / 2}$.

\section{Acknowledgments}

This work has been supported by the Project CCG07-UPM/ESP1632 of the Technical University of Madrid (UPM). Support to the UPM research groups included the IV PRICIT of the Comunidad Autónoma de Madrid, Spain.

\section{Appendix A. Supplementary data}

Supplementary data associated with this article can be found, in the online version, at doi:10.1016/j.adt.2010.08.002.

\section{References}

[1] C.R. Proffitt, C.J. Sansonetti, J. Reader, Astrophys. J. 557 (2001) 320.

[2] P. Chayer, M. Fontaine, G. Fontaine, F. Wesemael, J. Dupuis, Baltic Astron. 15 (2006) 131.

[3] S.J. O'Toole, Astron. Astrophys. 423 (2006) L25.

[4] C. Colón, A. Alonso-Medina, A. Zanón, J. Albéniz, Spectral Line Shapes, vol. 15, AIP Conf. Proc. 1058 (2008) 257.

[5] G.K. Schoepfle, Phys. Rev. 47 (1935) 232.

[6] M.F. Crawford, A.B. McLay, A.M. Crooker, Proc. R. Soc. Lond. A 158 (1937) 455.

[7] F. Gutmann, A.M. Crooker, Can. J. Phys. 51 (1973) 1823.

[8] A.J.J. Raassen, Y.N. Joshi, J.F. Wyart, Phys. Lett. A 154 (1991) 453.

[9] E.P. Trukhan, L.I. Kiselevskii, Acad. Nav. BSSR (Minsk) Doklady 11 (1967) 122.

[10] J. Migdalek, W.E. Baylis, J. Quant. Spectros. Radiat. Transfer 22 (1979) 113.

[11] J. Migdalek, M. Garmulewicz, J. Phys. B Atom. Mol. Opt. Phys. 33 (2000) 1735.

[12] H.-S. Chou, W.R. Johnson, Phys. Rev. A 56 (1997) 2424.

[13] U.I. Safronova, W.R. Johnson, Phys. Rev. A 69 (2004) 052511.

[14] T. Andersen, A.K. Nielsen, G. Sørensen, Phys. Scr. 6 (1972) 122.

[15] E.H. Pinnington, W. Ansbacher, A. Tauheed, J.A. Kernahan, Can. J. Phys. 69 (1991) 594.

[16] W. Ansbacher, E.H. Pinnington, J.A. Kernahan, Can. J. Phys. 66 (1988) 402

[17] C.E. Moore, Atomic Energy Levels, NBS Circular 467, vol. 14, Washington, DC, 1958.

[18] R.D. Cowan, The Theory of Atomic Structure and Spectra, University of California Press, Berkeley, 1981.

[19] A. Alonso-Medina, C. Colôn, A. Zanón, Mon. Not. R. Astron. Soc. 395 (2009) 567.

[20] J. Migdalek, W.E. Baylis, J. Phys. B: Atom. Mol. Opt. Phys. 11 (1978) L497.

[21] S. Hameed, J. Phys. B: Atom. Mol. Opt. Phys. 5 (1972) 746.

[22] S. Fraga, J. Karwowski, K.M.S. Saxena, Handbook of Atomic Data, Elsevier, Amsterdam, 1976

[23] W.C. Martin, W.L. Wiese, Atomic Spectroscopy, in: G.W.F. Drake (Ed.), Atomic, Molecular and Optical Physics Handbook, AIP Press, New York, 1996, p. 135 (Chapter 10).

[24] J.B. Green, R.A. Loring, Phys. Rev. 43 (1933) 459 


\section{Explanation of Tables}

Table 1. Energy levels and wavefunctions calculated in Pb IV

$\begin{array}{ll}\text { Levels } & \text { Numbers assigned to each level } \\ \text { Energy } & \text { Energy of each level, in } \mathrm{cm}^{-1} \\ \text { Lande factor } & \text { The Lande factor calculated in this work } \\ J & \text { The total angular moment } \\ \text { Wavefunctions } & \text { The wavefunction corresponding to each level } \\ \% 1 \mathrm{st} & \text { Leading percentage of principal } L S \text { component } \\ \% 2 \mathrm{nd} & \text { Leading percentage of other } L S \text { components } \\ \text { Comp } & L S \text { components of each level }\end{array}$

Table 2. Parameters resulting from the least-square fitting of the intermediate coupling calculations Configuration The configuration, with $[\mathrm{Xe}] 4 \mathrm{f}^{14}$ truncated Parameters Parameters, in $\mathrm{cm}^{-1}$ $E_{a v} \quad$ Energy configuration average $F^{k}, G^{k} \quad$ Coulomb radial integrals

$\zeta_{n l} \quad$ Spin-orbit energy

$R_{\mathrm{d}}^{\mathrm{k}} \quad$ Direct configuration interaction integral

$R_{\mathrm{e}}{ }^{\mathrm{k}} \quad$ Exchange configuration interaction integral

Table 3. Oscillator strengths and transition probabilities of spectral lines arising from $5 d^{10} n$ s configurations and radiative lifetimes of Pb IV

First column Transitions levels, the lower and upper levels

Second column Wavelength, in $\AA$

Third column $\quad$ Transitions probabilities in $\mathrm{s}^{-1}$

Fourth column $\quad$ Oscillator strengths ( $f$-values)

Fifth column Lifetimes, in ns

Table 4. Oscillator strengths and transition probabilities of spectral lines arising from $5 d^{10} 6 p$ and $5 d^{9} 6 s 6 p$ configurations and radiative lifetimes of $\mathrm{Pb}$ IV

Same as for Table 3

Table 5. Oscillator strengths and transition probabilities of spectral lines arising from $5 d^{10}$ nd configuration and radiative lifetimes of $\mathrm{Pb}$ IV

Same as for Table 3

Table 6. Oscillator strengths and transition probabilities of spectral lines arising from $5 \mathrm{~d}^{10} 5 \mathrm{~g}$ and $5 \mathrm{~d}^{10}$ nh configurations and radiative lifetimes of $\mathbf{P b}$ IV

Same as for Table 3 
Table 1

Energy levels and wavefunctions calculated in $\mathrm{Pb}$ IV. See page 40 for Explanation of Tables.

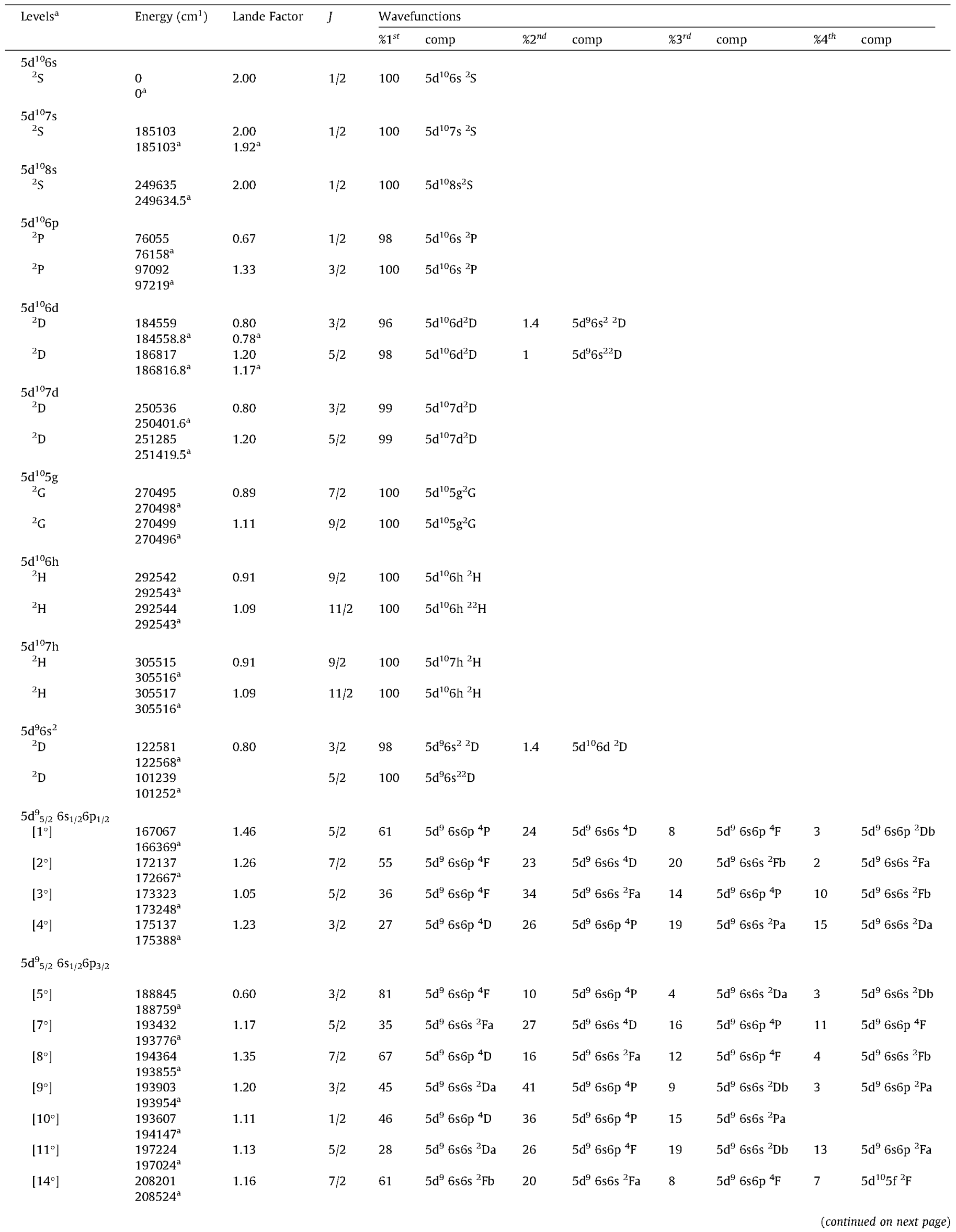


Table 1 (continued)

\begin{tabular}{|c|c|c|c|c|c|c|c|c|c|c|c|}
\hline \multirow[t]{2}{*}{ Levels $^{\mathrm{a}}$} & \multirow[t]{2}{*}{ Energy $\left(\mathrm{cm}^{1}\right)$} & \multirow[t]{2}{*}{ Lande Factor } & \multirow[t]{2}{*}{$J$} & \multicolumn{8}{|c|}{ Wavefunctions } \\
\hline & & & & $\% 1^{s t}$ & comp & $\% 2^{\text {nd }}$ & comp & $\% 3^{r d}$ & comp & $\% 4^{t h}$ & comp \\
\hline \multicolumn{12}{|c|}{$5 d^{9}{ }_{5 / 2} 6 s_{1 / 2} 6 p_{3 / 2}$} \\
\hline$\left[12^{\circ}\right]$ & $\begin{array}{l}199979 \\
200021^{\mathrm{a}}\end{array}$ & 1.22 & $3 / 2$ & 55 & $5 \mathrm{~d}^{9} 6 \mathrm{~s} 6 \mathrm{~s}^{2} \mathrm{~Pa}$ & 24 & $5 d^{9} 6 s 6 s{ }^{4} D$ & 11 & $5 d^{9} 6 s 6 s^{2} \mathrm{Db}$ & 8 & $5 d^{9} 6 s 6 s^{2} \mathrm{~Pb}$ \\
\hline$\left[13^{\circ}\right]$ & 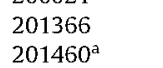 & 0.58 & $1 / 2$ & 36 & $5 d^{9} 6 s 6 s^{2} \mathrm{~Pa}$ & 36 & $5 d^{9} 6 s 6 s^{2} \mathrm{~Pb}$ & 18 & $5 d^{9} 6 s 6 s^{4} D$ & 4 & $5 \mathrm{~d}^{10} 7 \mathrm{p}^{2} \mathrm{P}$ \\
\hline$\left[15^{\circ}\right]$ & $\begin{array}{l}209126 \\
209051^{\mathrm{a}}\end{array}$ & 1.26 & $3 / 2$ & 58 & $5 d^{9} 6 s 6 s^{2} \mathrm{~Pb}$ & 20 & $5 d^{10} 7 p^{2} \mathrm{P}$ & 9 & $5 d^{9} 6 s 6 s^{2} \mathrm{Db}$ & 4 & $5 d^{9} 6 s 6 s^{2} \mathrm{~Pa}$ \\
\hline$\left[18^{\circ}\right]$ & $\begin{array}{l}213448 \\
213519^{a}\end{array}$ & 1.18 & $5 / 2$ & 66 & $5 d^{9} 6 s 6 s^{2} \mathrm{Db}$ & 13 & $5 d^{9} 6 s 6 p^{4} D$ & 8 & $5 d^{9} 6 s 6 s^{2} \mathrm{Fb}$ & 6 & $5 d^{9} 6 s 6 s^{2} \mathrm{Da}$ \\
\hline \multicolumn{12}{|c|}{$5 d^{9}{ }_{5 / 2} 6 s_{1 / 2} 6 p_{3 / 2}$} \\
\hline$\left[16^{\circ}\right]$ & $\begin{array}{l}209839 \\
209788^{\mathrm{a}}\end{array}$ & $\begin{array}{l}0.94 \\
0.68^{\mathrm{a}}\end{array}$ & $1 / 2$ & 64 & $5 d^{10} 7 p^{2} p$ & 19 & $5 d^{9} 6 s 6 p^{4} P$ & 15 & $5 d^{9} 6 s 6 s^{4} D$ & & \\
\hline$\left[17^{\circ}\right]$ & $\begin{array}{l}210363 \\
210370^{\mathrm{a}}\end{array}$ & 1.42 & $1 / 2$ & 41 & $5 d^{9} 6 s 6 p^{4} P$ & 29 & $5 \mathrm{~d}^{10} 7 \mathrm{p}^{2} \mathrm{P}$ & 19 & $5 d^{9} 6 s 6 s^{2} \mathrm{~Pa}$ & 10 & $5 d^{9} 6 s 6 s^{4} D$ \\
\hline$\left[19^{\circ}\right]$ & $\begin{array}{l}214394 \\
214842^{\mathrm{a}}\end{array}$ & 1.25 & $3 / 2$ & 40 & $5 d^{9} 6 s 6 p^{4} D$ & 17 & $5 d^{9} 6 s 6 p^{4} P$ & 15 & $5 d^{10} 7 p^{2} P$ & 9 & $5 d^{9} 6 s 6 s^{2} \mathrm{Da}$ \\
\hline$\left[20^{\circ}\right]$ & $\begin{array}{l}215177 \\
214892^{\mathrm{a}}\end{array}$ & 1.18 & $7 / 2$ & 41 & $5 d^{9} 6 s 6 s^{2} \mathrm{Fa}$ & 25 & $5 d^{9} 6 s 6 p^{4} F$ & 14 & $5 d^{10} 5 f^{2} F$ & 13 & $5 d^{9} 6 s 6 s^{2} F b$ \\
\hline$\left[21^{\circ}\right]$ & $\begin{array}{l}217203 \\
217216^{a}\end{array}$ & 1.18 & $5 / 2$ & 40 & $5 d^{9} 6 s 6 s^{2} \mathrm{Da}$ & 24 & $5 d^{9} 6 s 6 s{ }^{4} D$ & 15 & $5 d^{9} 6 s 6 s^{2} \mathrm{Fb}$ & 11 & $5 d^{9} 6 s 6 p{ }^{4} F$ \\
\hline$\left[22^{\circ}\right]$ & $\begin{array}{l}217965 \\
217851^{\mathrm{a}}\end{array}$ & $\begin{array}{l}1.32 \\
1.29^{a}\end{array}$ & $3 / 2$ & 64 & $5 d^{10} 7 p^{2} P$ & 26 & $5 d^{9} 6 s 6 s^{2} \mathrm{~Pb}$ & 6 & $5 d^{9} 6 s 6 s{ }^{4} D$ & 1 & $5 d^{9} 6 s 6 p{ }^{4} P$ \\
\hline$\left[23^{\circ}\right]$ & $\begin{array}{l}219451 \\
219461^{\text {a }}\end{array}$ & 0.88 & $5 / 2$ & 92 & $5 d^{10} 5 f^{2} F$ & 3 & $5 d^{9} 6 s 6 s^{2} \mathrm{Da}$ & 2 & $5 d^{9} 6 s 6 s^{2} \mathrm{Fb}$ & 1 & $5 d^{9} 6 s 6 s^{2} D b$ \\
\hline$\left[24^{\circ}\right]$ & $\begin{array}{l}221706 \\
221716^{a}\end{array}$ & 1.15 & $7 / 2$ & 78 & $5 d^{10} 5 f^{2} F$ & 18 & $5 \mathrm{~d}^{9} 6 \mathrm{~s} 6 \mathrm{~s}^{2} \mathrm{Fa}$ & 1 & $5 d^{9} 6 s 6 p^{4} F$ & 1 & $5 d^{9} 6 s 6 s{ }^{4} D$ \\
\hline$\left[25^{\circ}\right]$ & $\begin{array}{l}231375 \\
231013^{\mathrm{a}}\end{array}$ & 0.61 & $1 / 2$ & 59 & $5 d^{9} 6 s 6 s^{2} \mathrm{~Pb}$ & 27 & $5 \mathrm{~d}^{9} 6 \mathrm{~s} 6 \mathrm{~s}^{2} \mathrm{~Pa}$ & 9 & $5 d^{9} 6 s 6 s^{4} D$ & 3 & $5 d^{10} 7 p^{2} p$ \\
\hline$\left[26^{\circ}\right]$ & $\begin{array}{l}232854 \\
232638^{\mathrm{a}}\end{array}$ & 0.93 & $5 / 2$ & 61 & $5 d^{9} 6 s 6 s^{2} \mathrm{Fb}$ & 14 & $5 d^{9} 6 s 6 s^{2} \mathrm{Da}$ & 13 & $5 d^{9} 6 s 6 s^{2} \mathrm{Fa}$ & 4 & $5 d^{10} 5 f^{2} F$ \\
\hline$\left[27^{\circ}\right]$ & $\begin{array}{l}235808 \\
235565^{\mathrm{a}}\end{array}$ & 0.85 & $3 / 2$ & 61 & $5 d^{9} 6 s 6 s^{2} \mathrm{Db}$ & 25 & $5 d^{9} 6 s 6 s^{2} \mathrm{Da}$ & 7 & $5 d^{9} 6 s 6 s^{2} \mathrm{~Pa}$ & 3 & $5 d^{9} 6 s 6 p^{4} F$ \\
\hline
\end{tabular}

a Moore [17]. 
Table 2

Parameters resulting from the least-square fitting of the intermediate coupling calculations. See page 40 for Explanation of Tables.

\begin{tabular}{|c|c|c|c|c|c|c|c|}
\hline $\begin{array}{l}\text { Configuration } \\
5 d^{9} 6 s 6 p\end{array}$ & & \multicolumn{3}{|c|}{ Parameters ( $\left.\mathrm{cm}_{\text {minus } 1}\right)$} & & & \\
\hline $5 d^{9} 6 s 6 p$ & $E_{a \nu}=199394$ & $\begin{array}{l}\mathrm{F}^{1}(5 \mathrm{~d}, 6 \mathrm{p})= \\
\mathrm{F}^{2}(5 \mathrm{~d}, 6 \mathrm{p})= \\
\mathrm{G}^{2}(5 \mathrm{~d}, 6 \mathrm{~s})= \\
\mathrm{G}^{1}(5 \mathrm{~d}, 6 \mathrm{p})= \\
\mathrm{G}^{2}(5 \mathrm{~d}, 6 \mathrm{p})= \\
\mathrm{G}^{3}(5 \mathrm{~d}, 6 \mathrm{p})= \\
\mathrm{G}^{1}(6 \mathrm{~s}, 6 \mathrm{p})=\end{array}$ & $\begin{array}{l}-2280 \\
23477 \\
17570 \\
9965 \\
-2771 \\
15128 \\
33655\end{array}$ & $\begin{array}{l}(0) \\
(26379) \\
(18735) \\
(9660) \\
(0) \\
(8481) \\
(45752)\end{array}$ & $\begin{array}{l}\zeta_{5 d}= \\
\zeta_{6 p}=\end{array}$ & $\begin{array}{l}8779 \\
15415\end{array}$ & $\begin{array}{l}(8735) \\
(14592)\end{array}$ \\
\hline $5 d^{10} 7 p$ & $E_{a v}=213743$ & & & & $\zeta_{7 p}=$ & 3654 & $(4382)$ \\
\hline $5 d^{10} 5 f$ & $E_{a v}=219709$ & & & & $\zeta_{5 f}=$ & 14 & $(56)$ \\
\hline $5 d^{10} 7 p-5 d^{9} 6 s 6 p$ & $\begin{array}{l}R_{\mathrm{d}}^{2}(5 \mathrm{~d} 5 \mathrm{~d}, 5 \mathrm{~d} 6 \mathrm{~s})= \\
R_{\mathrm{d}}^{2}(5 \mathrm{~d} 7 \mathrm{p}, 6 \mathrm{~s} 6 \mathrm{p})= \\
R_{\mathrm{e}}^{1}(5 \mathrm{~d} 7 \mathrm{p}, 6 \mathrm{~s} 6 \mathrm{p})=\end{array}$ & $\begin{array}{l}0 \\
-6899 \\
-6397\end{array}$ & $\begin{array}{l}(0) \\
(-6366) \\
(-5903)\end{array}$ & & & & \\
\hline $5 d^{10} 5 f-5 d^{9} 6 s 6 p$ & $\begin{array}{l}R_{\mathrm{d}}^{2}(5 \mathrm{~d} 5 \mathrm{f}, 6 \mathrm{~s} 6 \mathrm{p})= \\
R_{\mathrm{e}}^{3}(5 \mathrm{~d} 5 \mathrm{f}, 6 \mathrm{~s} 6 \mathrm{p})=\end{array}$ & $\begin{array}{l}14993 \\
9655\end{array}$ & $\begin{array}{l}(14785) \\
(9521)\end{array}$ & & & & \\
\hline
\end{tabular}

Values in parentheses are HFR results. 
Table 3

Oscillator strengths and transition probabilities of spectral lines arising from $5 \mathrm{~d}^{10} \mathrm{~ns}$ configurations and radiative lifetimes of Pb IV. See page 40 for Explanation of Tables.

\begin{tabular}{|c|c|c|c|c|c|c|c|}
\hline \multicolumn{2}{|c|}{ Transition Levels ${ }^{a}$} & \multirow[t]{2}{*}{ Wavelength $\lambda(\AA)^{a}$} & \multirow[t]{2}{*}{ Transition probabilities $\left(10^{8} \mathrm{~s}^{-1}\right)$} & \multicolumn{2}{|l|}{ f-Values } & \multicolumn{2}{|c|}{ Lifetimes (ns) } \\
\hline Upper & Lower & & & This work & Others & This work & Others \\
\hline \multirow[t]{2}{*}{$7 \mathrm{~s}^{2} \mathrm{~S}_{1 / 2}$} & $6 \mathrm{p}^{2} \mathrm{P}_{1 / 2}$ & 917.9 & 18.6 & 0.235 & $\begin{array}{l}0.17^{b} \\
0.162^{c} \\
0.162^{c}\end{array}$ & 0.26 & $0.35 \pm 0.5^{d}$ \\
\hline & $6 p^{2} p_{3 / 2}$ & 1137.9 & 19.4 & 0.188 & $\begin{array}{l}0.234^{b} \\
0.224^{\mathrm{c}}\end{array}$ & & \\
\hline \multirow[t]{13}{*}{$8 s^{2} S_{1 / 2}$} & $6 p^{2} P_{1 / 2}$ & 576.4 & 5.6 & 0.028 & $\begin{array}{l}0.0275^{c} \\
0.005^{c}\end{array}$ & 0.44 & $0.47 \pm 0.04^{\mathrm{e}}$ \\
\hline & $6 p^{2} P_{3 / 2}$ & 656.1 & 7.71 & 0.0249 & $\begin{array}{l}0.0298^{\mathrm{C}} \\
0.0286^{\mathrm{C}}\end{array}$ & & \\
\hline & $5 d^{9} 6 s 6 p\left[4^{\circ}\right]_{3 / 2}$ & 1346.9 & 0.013 & 0.00018 & & & \\
\hline & $5 d^{9} 6 \mathrm{~s} 6 \mathrm{p}\left[10^{\circ}\right]_{1 / 2}$ & 1802.2 & 0.0063 & 0.00031 & & & \\
\hline & $5 d^{9} 6 s 6 p\left[9^{\circ}\right]_{3 / 2}$ & 1795.9 & 0.0072 & 0.00003 & & & \\
\hline & $5 d^{9} 6 s 6 p\left[12^{\circ}\right]_{3 / 2}$ & 2015.6 & 0.0198 & 0.00060 & & & \\
\hline & $5 d^{9} 6 s 6 p\left[13^{\circ}\right]_{1 / 2}$ & 2075.8 & 0.31 & 0.020 & & & \\
\hline & $5 d^{9} 6 s 6 p\left[15^{\circ}\right]_{3 / 2}$ & 2464.1 & 1.70 & 0.077 & & & \\
\hline & $5 d^{9} 6 s 6 p\left[16^{\circ}\right]_{1 / 2}$ & 2509.6 & 2.6 & 0.24 & $\begin{array}{l}0.265^{c} \\
0.262^{c}\end{array}$ & & \\
\hline & $5 d^{9} 6 s 6 \mathrm{p}\left[17^{\circ}\right]_{1 / 2}$ & 2546.8 & 1.12 & 0.109 & & & \\
\hline & $5 d^{9} 6 s 6 p\left[19^{\circ}\right]_{3 / 2}$ & 2874.2 & 0.83 & 0.051 & & & \\
\hline & $5 d^{9} 6 s 6 p\left[22^{\circ}\right]_{3 / 2}$ & 3146.4 & 2.6 & 0.193 & $\begin{array}{l}0.359^{c} \\
0.353^{c}\end{array}$ & & \\
\hline & $5 d^{9} 6 s 6 p\left[25^{\circ}\right]_{1 / 2}$ & 5370.1 & 0.0096 & 0.0041 & & & \\
\hline $5 d^{9} 6 s^{22} D_{3 / 2}$ & $\begin{array}{l}6 p^{2} P_{1 / 2} \\
6 p^{2} P^{2}\end{array}$ & $\begin{array}{l}2154.7 \\
3944.9\end{array}$ & $\begin{array}{l}0.086 \\
0.0003\end{array}$ & $\begin{array}{l}0.012 \\
0.00007\end{array}$ & & 116 & $100 \pm 10^{\mathrm{d}}$ \\
\hline
\end{tabular}

a Moore [17].

Migdalek [11].

Safronova [13].

d Ansbacher [16].

e Pinnington [15]. 
Table 4

Oscillator strengths and transition probabilities of spectral lines arising from $5 \mathrm{~d}^{10} 6 \mathrm{p}$ and $5 \mathrm{~d}^{9} 6 \mathrm{~s} 6 \mathrm{p}$ configurations and radiative lifetimes of Pb IV. See page 40 for Explanation of Tables.

\begin{tabular}{|c|c|c|c|c|c|c|c|}
\hline \multicolumn{2}{|l|}{ Transition Levels ${ }^{\mathrm{a}}$} & \multirow[t]{2}{*}{ Wavelength $\lambda(\AA)^{a}$} & \multirow[t]{2}{*}{ Transition probabilities $\left(10^{8} \mathrm{~s}^{-1}\right)$} & \multicolumn{2}{|l|}{ f-Values } & \multicolumn{2}{|c|}{ Lifetimes (ns) } \\
\hline Upper & Lower & & & This work & Others & This work & Others \\
\hline $6 \mathrm{p}^{2} \mathrm{P}_{1 / 2}$ & $6 s^{2} S_{1 / 2}$ & 1313.1 & 5.7 & 0.15 & $\begin{array}{l}0.22^{\mathrm{b}} \\
0.375^{\mathrm{c}} \\
0.219^{\mathrm{c}}\end{array}$ & 1.75 & $\begin{array}{l}1.11 \pm 0.10^{\mathrm{d}} \\
1.40^{\mathrm{g}}\end{array}$ \\
\hline $6 p^{2} P_{3 / 2}$ & $6 s^{2} S_{1 / 2}$ & 1028.6 & 11.9 & 0.38 & $\begin{array}{l}0.58^{b} \\
0.932^{c} \\
0.568^{c} \\
0.73 \pm 0.10^{f}\end{array}$ & 0.84 & $\begin{array}{l}0.78 \pm 0.10^{f} \\
0.52 \pm 0.04^{d} \\
0.63^{g}\end{array}$ \\
\hline $5 \mathrm{~d}^{9} 6 \mathrm{~s} 6 \mathrm{p}\left[1^{\circ}\right]_{5 / 2}$ & $5 d^{9} 6 s^{22} D_{5 / 2}$ & 1535.7 & 0.11 & 0.0039 & & 87.9 & \\
\hline $5 \mathrm{~d}^{9} 6 \mathrm{~s} 6 \mathrm{p}\left[2^{\circ}\right]_{7 / 2}$ & $5 d^{9} 6 s^{22} D_{5 / 2}$ & 1400.3 & 0.85 & 0.033 & & 11.7 & $9.8 \pm 0.3^{e}$ \\
\hline $5 d^{9} 6 s 6 p\left[3^{\circ}\right]_{5 / 2}$ & $\begin{array}{l}5 d^{9} 6 s^{22} D_{5 / 2} \\
5 d^{9} 6 s^{22} D_{3 / 2}\end{array}$ & $\begin{array}{l}1389.0 \\
1973.2\end{array}$ & $\begin{array}{l}0.46 \\
0.0025\end{array}$ & $\begin{array}{l}0.015 \\
0.00022\end{array}$ & & 21.4 & $20.9 \pm 0.5^{\mathrm{e}}$ \\
\hline $5 d^{9} 6 s 6 p[4]_{3 / 2}$ & $\begin{array}{l}6 \mathrm{~s}^{2} \mathrm{~s}_{1 / 2} \\
5 \mathrm{~d}^{9} 6 \mathrm{~s}^{22} \mathrm{D}_{5 / 2} \\
5 \mathrm{~d}^{9} 6 \mathrm{~s}^{22} \mathrm{D}_{3 / 2}\end{array}$ & $\begin{array}{l}570.2 \\
1348.9 \\
1893.2\end{array}$ & $\begin{array}{l}0.00067 \\
1.06 \\
0.0061\end{array}$ & $\begin{array}{l}0.000006 \\
0.019 \\
0.00033\end{array}$ & & 9.4 & \\
\hline $5 d^{9} 6 s 6 p\left[5^{\circ}\right]_{3 / 2}$ & $\begin{array}{l}6 s^{2} S_{1 / 2} \\
5 d^{9} 6 s^{22} D_{5 / 2} \\
5 d^{9} 6 s^{22} D_{3 / 2}\end{array}$ & $\begin{array}{l}529.8 \\
1142.8 \\
1510.8\end{array}$ & $\begin{array}{l}0.037 \\
0.0408 \\
0.18\end{array}$ & $\begin{array}{l}0.00031 \\
0.00053 \\
0.0062\end{array}$ & & 3.9 & $6.6 \pm 0.3^{\mathrm{e}}$ \\
\hline $5 d^{9} 6 s 6 p\left[7^{\circ / 2}\right.$ & $\begin{array}{l}5 \mathrm{~d}^{9} 6 \mathrm{~s}^{22} \mathrm{D}_{5 / 2} \\
5 \mathrm{~d}^{9} 6 \mathrm{~s}^{22} \mathrm{D}_{3 / 2}\end{array}$ & $\begin{array}{l}1080.8 \\
1404.3\end{array}$ & $\begin{array}{l}0.44 \\
0.267\end{array}$ & $\begin{array}{l}0.0077 \\
0.012\end{array}$ & & 14.2 & \\
\hline $5 d^{9} 6 s 6 p\left[8^{\circ}\right]_{7 / 2}$ & $5 d^{9} 6 s^{2}{ }^{2} D_{5 / 2}$ & 1079.9 & 0.032 & 0.00075 & & 312 & \\
\hline $5 d^{9} 6 s 6 p\left[9^{\circ}\right]_{3 / 2}$ & $\begin{array}{l}6 \mathrm{~s}^{2} \mathrm{~s}_{1 / 2} \\
5 \mathrm{~d}^{9} 6 \mathrm{~s}^{22} \mathrm{D}_{5 / 2} \\
5 \mathrm{~d}^{9} 6 \mathrm{~s}^{22} \mathrm{D}_{3 / 2}\end{array}$ & $\begin{array}{l}515.6 \\
1078.7 \\
1400.8\end{array}$ & $\begin{array}{l}0.0082 \\
0.58 \\
0.0035\end{array}$ & $\begin{array}{l}0.00006 \\
0.0067 \\
0.00010\end{array}$ & & 17.0 & \\
\hline $5 d^{9} 6 s 6 p\left[10^{\circ}\right]_{1 / 2}$ & $\begin{array}{l}6 s^{2} s_{1 / 2} \\
5 d^{9} 6 s^{22} D_{3 / 2}\end{array}$ & $\begin{array}{l}515.1 \\
1397.1\end{array}$ & $\begin{array}{l}0.045 \\
0.45\end{array}$ & $\begin{array}{l}0.00018 \\
0.0066\end{array}$ & & 20.2 & \\
\hline $5 d^{9} 6 s 6 p\left[11^{\circ}\right]_{5 / 2}$ & $\begin{array}{l}5 d^{9} 6 s^{22} D_{5 / 2} \\
5 d^{9} 6 s^{22} D_{3 / 2} \\
6 d^{2} D_{3 / 2}\end{array}$ & $\begin{array}{l}1044.2 \\
1343.1 \\
8022.3\end{array}$ & $\begin{array}{l}0.055 \\
0.85 \\
0.00033\end{array}$ & $\begin{array}{l}0.00090 \\
0.034 \\
0.00048\end{array}$ & & 11.0 & \\
\hline $5 d^{9} 6 s 6 p\left[12^{\circ}\right]_{3 / 2}$ & $\begin{array}{l}6 s^{2} S_{1 / 2} \\
5 d^{9} 6 s^{22} D_{5 / 2} \\
5 d^{9} 6 s^{22} D_{3 / 2} \\
7 s^{2} S_{1 / 2}\end{array}$ & $\begin{array}{l}499.9 \\
1012.5 \\
1291.1 \\
6703.3\end{array}$ & $\begin{array}{l}2.3 \\
1.0 \\
0.50 \\
0.00059\end{array}$ & $\begin{array}{l}0.017 \\
0.010 \\
0.012 \\
0.00079\end{array}$ & & 2.6 & \\
\hline $5 d^{9} 6 s 6 p\left[13^{\circ}\right]_{1 / 2}$ & $\begin{array}{l}6 \mathrm{~s}^{2} \mathrm{~S}_{1 / 2} \\
5 \mathrm{~d}^{9} 6 \mathrm{~s}^{22} \mathrm{D}_{3 / 2} \\
6 \mathrm{~d}^{2} \mathrm{D}_{3 / 2} \\
7 \mathrm{~s}^{2} \mathrm{~S}_{1 / 2}\end{array}$ & $\begin{array}{l}496.4 \\
1267.6 \\
5916.7 \\
6113.6\end{array}$ & $\begin{array}{l}6.1 \\
0.38 \\
0.031 \\
0.023\end{array}$ & $\begin{array}{l}0.022 \\
0.0046 \\
0.0081 \\
0.013\end{array}$ & & 1.3 & \\
\hline $5 d^{9} 6 s 6 p\left[14^{\circ}\right]_{7 / 2}$ & $\begin{array}{l}5 d^{9} 6 s^{2}{ }^{2} D_{5 / 2} \\
6 d^{2} D_{5 / 2}\end{array}$ & $\begin{array}{l}932.2 \\
4606.8\end{array}$ & $\begin{array}{l}26.2 \\
0.041\end{array}$ & $\begin{array}{l}0.46 \\
0.017\end{array}$ & & 0.381 & $0.353 \pm 0.015^{\mathrm{e}}$ \\
\hline $5 d^{9} 6 s 6 p\left[15^{\circ}\right]_{3 / 2}$ & $\begin{array}{l}6 s^{2} s_{1 / 2} \\
5 d^{9} 6 s^{22} D_{5 / 2} \\
5 d^{9} 6 s^{22} D_{3 / 2} \\
6 d^{2} D_{3 / 2} \\
6 d^{2} D_{5 / 2} \\
7 s^{2} s_{1 / 2}\end{array}$ & $\begin{array}{l}478.4 \\
927.6 \\
1156.3 \\
4082.9 \\
4497.6 \\
4175.7\end{array}$ & $\begin{array}{l}6.7 \\
16.1 \\
0.052 \\
0.041 \\
0.30 \\
0.34\end{array}$ & $\begin{array}{l}0.046 \\
0.14 \\
0.0010 \\
0.010 \\
0.061 \\
0.18\end{array}$ & & 0.42 & \\
\hline${ }^{*} 5 \mathrm{~d}^{9} 6 \mathrm{~s} 6 \mathrm{p}\left[16^{\circ}\right]_{1 / 2}$ & $6 s^{2} S_{1 / 2}$ & 476.7 & 1.84 & 0.0063 & $\begin{array}{l}0.0008^{c} \\
0.019^{c}\end{array}$ & 2.42 & $\begin{array}{l}2.90 \pm 0.15^{\mathrm{e}} \\
3.58 \pm 0.15^{\mathrm{e}}\end{array}$ \\
\hline & $\begin{array}{l}5 d^{9} 6 s^{22} D_{3 / 2} \\
6 d^{2} D_{3 / 2}\end{array}$ & $\begin{array}{l}1146.5 \\
3963.6\end{array}$ & $\begin{array}{l}0.12 \\
1.1\end{array}$ & $\begin{array}{l}0.0012 \\
0.129\end{array}$ & $\begin{array}{l}0.236^{c} \\
0.224^{c}\end{array}$ & & \\
\hline & $7 s^{2} S_{1 / 2}$ & 4051.0 & 1.1 & 0.271 & $\begin{array}{l}0.489^{\mathrm{c}} \\
0.430^{\mathrm{c}}\end{array}$ & & \\
\hline $5 d^{9} 6 s 6 p\left[17^{\circ}\right]_{1 / 2}$ & $\begin{array}{l}5 d^{9} 6 s^{22} D_{3 / 2} \\
6 d^{2} D_{3 / 2} \\
7 s^{2} S_{1 / 2}\end{array}$ & $\begin{array}{l}1138.9 \\
3874.3 \\
3957.8\end{array}$ & $\begin{array}{l}0.30 \\
0.53 \\
0.51\end{array}$ & $\begin{array}{l}0.0029 \\
0.060 \\
0.012\end{array}$ & & 9.4 & \\
\hline $5 d^{9} 6 s 6 p\left[18^{\circ}\right]_{5 / 2}$ & $\begin{array}{l}5 d^{9} 6 s^{2}{ }^{2} D_{5 / 2} \\
5 d^{9} 6 s^{22} D_{3 / 2} \\
6 d^{2} D_{3 / 2} \\
6 d^{2} D_{5 / 2}\end{array}$ & $\begin{array}{l}890.7 \\
1099.5 \\
3453.0 \\
3745.0\end{array}$ & $\begin{array}{l}26.5 \\
0.075 \\
0.020 \\
0.00046\end{array}$ & $\begin{array}{l}0.31 \\
0.0020 \\
0.0054 \\
0.00010\end{array}$ & & 0.376 & $0.352 \pm 0.015^{\mathrm{e}}$ \\
\hline $5 d^{9} 6 s 6 p\left[19^{\circ}\right]_{3 / 2}$ & $\begin{array}{l}6 s^{2} s_{1 / 2} \\
5 d^{9} 6 s^{22} D_{5 / 2} \\
5 d^{9} 6 s^{22} D_{3 / 2} \\
6 d^{2} D_{3 / 2} \\
6 d^{2} D_{5 / 2} \\
7 s^{2} S_{1 / 2}\end{array}$ & $\begin{array}{l}465.5 \\
880.4 \\
1083.7 \\
3302.1 \\
3568.2 \\
3362.6\end{array}$ & $\begin{array}{l}1.8 \\
0.30 \\
0.071 \\
0.044 \\
0.30 \\
0.41\end{array}$ & $\begin{array}{l}0.012 \\
0.0023 \\
0.0012 \\
0.0072 \\
0.038 \\
0.14\end{array}$ & & 3.9 & \\
\hline
\end{tabular}


Table 4 (continued)

\begin{tabular}{|c|c|c|c|c|c|c|c|}
\hline \multicolumn{2}{|l|}{ Transition Levels $^{\mathrm{a}}$} & \multirow[t]{2}{*}{ Wavelength $\lambda(\AA)^{\mathrm{a}}$} & \multirow[t]{2}{*}{ Transition probabilities $\left(10^{8} \mathrm{~s}^{-1}\right)$} & \multicolumn{2}{|l|}{ f-Values } & \multicolumn{2}{|c|}{ Lifetimes (ns) } \\
\hline Upper & Lower & & & This work & Others & This work & Others \\
\hline $5 \mathrm{~d}^{9} 6 \mathrm{~s} 6 \mathrm{p}\left[20^{\circ}\right]_{7 / 2}$ & $\begin{array}{l}5 d^{9} 6 s^{22} D_{5 / 2} \\
6 d^{2} D_{5 / 2}\end{array}$ & $\begin{array}{l}880.0 \\
3561.9\end{array}$ & $\begin{array}{l}0.11 \\
0.26\end{array}$ & $\begin{array}{l}0.0017 \\
0.066\end{array}$ & & 27.1 & \\
\hline $5 d^{9} 6 s 6 p\left[21^{\circ}\right]_{5 / 2}$ & $\begin{array}{l}5 d^{9} 6 s^{2}{ }^{2} D_{5 / 2} \\
5 d^{9} 6 s^{22} D_{3 / 2} \\
6 d^{2} D_{3 / 2} \\
6 d^{2} D_{5 / 2}\end{array}$ & $\begin{array}{l}862.3 \\
1056.6 \\
3062.1 \\
3289.6\end{array}$ & $\begin{array}{l}4.1 \\
0.76 \\
0.058 \\
0.00058\end{array}$ & $\begin{array}{l}0.046 \\
0.019 \\
0.012 \\
0.00009\end{array}$ & & 1.6 & \\
\hline \multirow[t]{4}{*}{${ }^{*} 5 \mathrm{~d}^{9} 6 \mathrm{~s} 6 \mathrm{p}\left[22^{\circ}\right]_{3 / 2}$} & $6 s{ }^{2} S_{1 / 2}$ & 459.0 & 0.16 & 0.0010 & $\begin{array}{l}0.0087^{c} \\
0.0084^{c}\end{array}$ & 0.69 & $\begin{array}{l}0.48 \pm 0.05^{\mathrm{e}} \\
0.74 \pm 0.10^{\mathrm{e}}\end{array}$ \\
\hline & $\begin{array}{l}5 d^{9} 6 s^{22} D_{5 / 2} \\
5 d^{9} 6 s^{22} D_{3 / 2} \\
6 d^{2} D_{3 / 2}\end{array}$ & $\begin{array}{l}857.8 \\
1049.5 \\
3003.6\end{array}$ & $\begin{array}{l}10.0 \\
0.11 \\
0.23\end{array}$ & $\begin{array}{l}0.073 \\
0.0018 \\
0.0311\end{array}$ & $\begin{array}{l}0.048^{c} \\
0.047^{c}\end{array}$ & & \\
\hline & $6 d^{2} D_{5 / 2}$ & 3222.2 & 1.6 & 0.166 & $\begin{array}{l}0.297^{c} \\
0.287^{c}\end{array}$ & & \\
\hline & $7 \mathrm{~S}^{2} \mathrm{~S}_{1 / 2}$ & 3053.5 & 2.4 & 0.671 & $\begin{array}{l}1.17^{\mathrm{c}} \\
1.04^{\mathrm{c}}\end{array}$ & & \\
\hline \multirow[t]{3}{*}{${ }^{*} 5 \mathrm{~d}^{9} 6 \mathrm{~s} 6 \mathrm{p}\left[23^{\circ}\right]_{5 / 2}$} & $5 d^{9} 6 s^{22} D_{5 / 2}$ & 846.0 & 0.56 & 0.0060 & & 1.61 & $\begin{array}{l}1.50 \pm 0.15^{\mathrm{e}} \\
2.15 \pm 0.15^{\mathrm{e}}\end{array}$ \\
\hline & $\begin{array}{l}5 d^{9} 6 s^{22} D_{3 / 2} \\
6 d^{2} D_{3 / 2}\end{array}$ & $\begin{array}{l}1032.1 \\
2865.1\end{array}$ & $\begin{array}{l}2.6 \\
2.9\end{array}$ & $\begin{array}{l}0.62 \\
0.535\end{array}$ & $\begin{array}{l}0.878^{c} \\
0.671^{c}\end{array}$ & & \\
\hline & $6 \mathrm{~d}^{2} \mathrm{D}_{5 / 2}$ & 3063.3 & 0.18 & 0.0253 & $\begin{array}{l}0.0400^{c} \\
0.0306^{c}\end{array}$ & & \\
\hline \multirow[t]{2}{*}{${ }^{*} 5 \mathrm{~d}^{9} 6 \mathrm{~s} 6 \mathrm{p}\left[24^{\circ}\right]_{7 / 2}$} & $5 d^{9} 6 s^{2} D_{5 / 2}$ & 830.1 & 1.1 & 0.015 & & 2.55 & $\begin{array}{l}1.50 \pm 0.15^{\mathrm{e}} \\
2.15 \pm 0.15^{\mathrm{e}}\end{array}$ \\
\hline & $6 \mathrm{~d}^{2} \mathrm{D}_{5 / 2}$ & 2865.4 & 2.8 & 0.459 & $\begin{array}{l}0.791^{c} \\
0.608^{c}\end{array}$ & & \\
\hline $5 d^{9} 6 s 6 p\left[25^{\circ}\right]_{1 / 2}$ & $\begin{array}{l}6 \mathrm{~s}^{2} \mathrm{~S}_{1 / 2} \\
5 \mathrm{~d}^{9} 6 \mathrm{~s}^{22} \mathrm{D}_{3 / 2} \\
6 \mathrm{~d}^{2} \mathrm{D}_{3 / 2} \\
7 \mathrm{~s}^{2} \mathrm{~S}_{1 / 2}\end{array}$ & $\begin{array}{l}432.9 \\
922.1 \\
2152.7 \\
2178.2\end{array}$ & $\begin{array}{l}2.3 \\
27.8 \\
0.035 \\
0.19\end{array}$ & $\begin{array}{l}0.0065 \\
0.18 \\
0.0012 \\
0.014\end{array}$ & & 0.33 & \\
\hline $5 \mathrm{~d}^{9} 6 \mathrm{~s} 6 \mathrm{p}\left[26^{\circ}\right]_{5 / 2}$ & $\begin{array}{l}5 d^{9} 6 s^{22} D_{5 / 2} \\
5 d^{9} 6 s^{22} D_{3 / 2} \\
6 d^{2} D_{3 / 2} \\
6 d^{2} D_{5 / 2}\end{array}$ & $\begin{array}{l}761.1 \\
908.5 \\
2079.9 \\
2182.4\end{array}$ & $\begin{array}{l}0.45 \\
24.4 \\
0.69 \\
0.021\end{array}$ & $\begin{array}{l}0.0039 \\
0.45 \\
0.067 \\
0.0015\end{array}$ & & 0.39 & \\
\hline $5 d^{9} 6 s 6 p\left[27^{\circ}\right]_{3 / 2}$ & $\begin{array}{l}5 d^{9} 6 s^{22} D_{5 / 2} \\
5 d^{9} 6 s^{22} D_{3 / 2} \\
6 d^{2} D_{3 / 2} \\
6 d^{2} D_{5 / 2} \\
7 s^{2} S_{1 / 2}\end{array}$ & $\begin{array}{l}744.5 \\
885.0 \\
1960.6 \\
2051.4 \\
1981.7\end{array}$ & $\begin{array}{l}0.22 \\
31.9 \\
0.039 \\
0.0076 \\
0.011\end{array}$ & $\begin{array}{l}0.0012 \\
0.37 \\
0.0022 \\
0.00032 \\
0.0013\end{array}$ & & 0.31 & \\
\hline
\end{tabular}

a Moore [17].

b Migdalek [11].

c Safronova [13].

d Ansbacher [16].

e Pinnington [15]

f Andersen [14].

$g$ Migdalek [10].

* $\left[16^{\circ}\right],\left[22^{\circ}\right]$ must be designed as $5 \mathrm{~d}^{10} 7 \mathrm{p}^{2} \mathrm{P}_{1 / 2,3 / 2} ;\left[23^{\circ}\right],\left[24^{\circ}\right]$ must be designed as $5 \mathrm{~d}^{10} 5 \mathrm{f}^{2} \mathrm{~F}_{5 / 2,7 / 2}$; see Table 1 . 
Table 5

Oscillator strengths and transition probabilities of spectral lines arising from $5 \mathrm{~d}^{10} \mathrm{nd}$ configuration and radiative lifetimes of Pb IV. See page 40 for Explanation of Tables.

\begin{tabular}{|c|c|c|c|c|c|c|c|}
\hline \multicolumn{2}{|c|}{ Transition Levels } & \multirow[t]{2}{*}{ Wavelength $\lambda(\AA)^{a}$} & \multirow[t]{2}{*}{ Transition Probabilities $\left(10^{8} \mathrm{~s}^{-1}\right)$} & \multicolumn{2}{|l|}{ f-Values } & \multicolumn{2}{|c|}{ Lifetimes (ns) } \\
\hline Upper & Lower & & & This work & Others & This work & Others \\
\hline $6 d^{2} D_{3 / 2}$ & $6 p^{2} \mathrm{P}_{3 / 2}$ & 1144.9 & 36.9 & 0.0747 & $\begin{array}{l}0.92^{\mathrm{b}} \\
0.87^{\mathrm{b}} \\
1.19^{\mathrm{c}} \\
0.86^{\mathrm{c}} \\
0.088^{\mathrm{b}} \\
0.092^{\mathrm{b}} \\
0.124^{\mathrm{c}} \\
0.093^{\mathrm{c}}\end{array}$ & 0.25 & $\begin{array}{l}0.28 \pm 0.03^{\mathrm{d}} \\
0.281 \pm 0.025^{\mathrm{e}} \\
0.234 \pm 0.010^{\mathrm{e}} \\
0.26^{\mathrm{g}}\end{array}$ \\
\hline $6 d^{2} D_{5 / 2}$ & $6 p^{2} P_{3 / 2}$ & 1116.1 & 25.1 & 0.703 & $\begin{array}{l}0.89 \mathrm{~b} \\
0.84 \mathrm{~b} \\
1.12^{\mathrm{c}} \\
0.843^{\mathrm{c}}\end{array}$ & 0.398 & $\begin{array}{l}0.365 \pm 0.020^{\mathrm{e}} \\
0.345 \pm 00.26^{\mathrm{g}} \\
0.33^{\mathrm{g}}\end{array}$ \\
\hline \multirow[t]{20}{*}{$7 \mathrm{~d}^{2} \mathrm{D}_{3 / 2}$} & $6 \mathrm{p}^{2} \mathrm{P}_{1 / 2}$ & 573.9 & 3.1 & 0.0306 & $\begin{array}{l}0.109^{c} \\
0.050^{c}\end{array}$ & 0.72 & $0.88 \pm 0.05^{\mathrm{e}}$ \\
\hline & $6 p^{2} P_{3 / 2}$ & 652.8 & 0.43 & 0.00275 & $\begin{array}{l}0.0064^{c} \\
0.0026^{c}\end{array}$ & & \\
\hline & $5 \mathrm{~d}^{9} 6 \mathrm{~s} 6 \mathrm{p}\left[3^{\circ}\right]_{5 / 2}$ & 1296.1 & 0.016 & 0.00027 & & & \\
\hline & $5 d^{9} 6 s 6 p[4]_{3 / 2}$ & 1333.1 & 0.0024 & 0.00006 & & & \\
\hline & $5 \mathrm{~d}^{9} 6 \mathrm{~s} 6 \mathrm{p}\left[7^{\circ}\right]_{5 / 2}$ & 1766.0 & 0.043 & 0.0013 & & & \\
\hline & $5 \mathrm{~d}^{9} 6 \mathrm{~s} 6 \mathrm{p}\left[9^{\circ}\right]_{3 / 2}$ & 1771.5 & 0.0017 & 0.00008 & & & \\
\hline & $5 \mathrm{~d}^{9} 6 \mathrm{~s} 6 \mathrm{p}\left[10^{\circ}\right]_{1 / 2}$ & 1777.6 & 0.010 & 0.00095 & & & \\
\hline & $5 \mathrm{~d}^{9} 6 \mathrm{~s} 6 \mathrm{p}\left[11^{\circ}\right]_{5 / 2}$ & 1873.4 & 0.032 & 0.0011 & & & \\
\hline & $5 d^{9} 6 \mathrm{~s} 6 \mathrm{p}\left[12^{\circ}\right]_{3 / 2}$ & 1984.9 & 0.0024 & 0.00014 & & & \\
\hline & $5 \mathrm{~d}^{9} 6 \mathrm{~s} 6 \mathrm{p}\left[13^{\circ}\right]_{1 / 2}$ & 2043.2 & 0.62 & 0.078 & & & \\
\hline & $5 \mathrm{~d}^{9} 6 \mathrm{~s} 6 \mathrm{p}\left[15^{\circ}\right]_{3 / 2}$ & 2418.3 & 0.35 & 0.031 & & & \\
\hline & ${ }^{*} 5 d^{9} 6 s 6 p\left[16^{\circ}\right]_{1 / 2}$ & 2462.5 & 5.3 & & $1.31^{\mathrm{c}}$ & & \\
\hline & & & & 0.96 & $1.18^{\mathrm{c}}$ & & \\
\hline & $5 d^{9} 6 s 6 p\left[17^{\circ}\right]_{1 / 2}$ & 2498.8 & 2.3 & 0.43 & & & \\
\hline & $5 d^{9} 6 \mathrm{~s} 6 \mathrm{p}\left[18^{\circ}\right]_{5 / 2}$ & 2711.3 & 0.021 & 0.0015 & & & \\
\hline & $5 \mathrm{~d}^{9} 6 \mathrm{~s} 6 \mathrm{p}\left[19^{\circ}\right]_{3 / 2}$ & 2812.2 & 0.17 & 0.020 & & & \\
\hline & $5 \mathrm{~d}^{9} 6 \mathrm{~s} 6 \mathrm{p}\left[21^{\circ}\right]_{5 / 2}$ & 3013.3 & 0.0058 & & & & \\
\hline & ${ }^{*} 5 d^{9} 6 s 6 p\left[22^{\circ}\right]_{3 / 2}$ & 3072.2 & 0.54 & $\begin{array}{l}0.0053 \\
0.0764\end{array}$ & $\begin{array}{l}0.146^{\mathrm{c}} \\
0.131^{\mathrm{c}}\end{array}$ & & \\
\hline & ${ }^{*} 5 d^{9} 6 s 6 p\left[23^{\circ}\right]_{5 / 2}$ & 3232.0 & 0.96 & 0.100 & $\begin{array}{l}0.103^{c} \\
0.088^{c}\end{array}$ & & \\
\hline & $\begin{array}{l}5 d^{9} 6 s 6 p\left[25^{\circ}\right]_{1 / 2} \\
5 d^{9} 6 s 6 p\left[26^{\circ}\right]_{5 / 2}\end{array}$ & $\begin{array}{l}5157.7 \\
5629.6\end{array}$ & $\begin{array}{l}0.024 \\
0.0060\end{array}$ & $\begin{array}{l}0.019 \\
0.0019\end{array}$ & & & \\
\hline \multirow[t]{20}{*}{$7 d^{2} D_{5 / 2}$} & $6 \mathrm{p}^{2} \mathrm{P}_{3 / 2}$ & 648.5 & 2.6 & 0.025 & $\begin{array}{l}0.068^{c} \\
0.026^{c}\end{array}$ & 0.95 & $0.97 \pm 0.08^{\mathrm{e}}$ \\
\hline & $5 \mathrm{~d}^{9} 6 \mathrm{~s} 6 \mathrm{p}\left[2^{\circ}\right]_{7 / 2}$ & 1269.8 & 0.0048 & 0.00009 & & & \\
\hline & $5 \mathrm{~d}^{9} 6 \mathrm{~s} 6 \mathrm{p}\left[3^{\circ}\right]_{5 / 2}$ & 1279.2 & 0.0031 & 0.00008 & & & \\
\hline & $5 \mathrm{~d}^{9} 6 \mathrm{~s} 6 \mathrm{p}\left[4^{\circ}\right]_{3 / 2}$ & 1315.2 & 0.011 & 0.00043 & & & \\
\hline & $5 \mathrm{~d}^{9} 6 \mathrm{~s} 6 \mathrm{p}\left[7^{\circ}\right]_{5 / 2}$ & 1734.8 & 0.0028 & 0.00013 & & & \\
\hline & $5 \mathrm{~d}^{9} 6 \mathrm{~s} 6 \mathrm{p}\left[8^{\circ}\right]_{7 / 2}$ & 1729.2 & 0.012 & 0.00040 & & & \\
\hline & $5 d^{9} 6 s 6 p\left[9^{\circ}\right]_{3 / 2}$ & 1740.2 & 0.0077 & 0.00052 & & & \\
\hline & $5 d^{9} 6 s 6 p\left[11^{\circ}\right]_{5 / 2}$ & 1838.4 & 0.00091 & 0.00005 & & & \\
\hline & $5 \mathrm{~d}^{9} 6 \mathrm{~s} 6 \mathrm{p}\left[12^{\circ}\right]_{3 / 2}$ & 1945.6 & 0.029 & 0.0025 & & & \\
\hline & $5 \mathrm{~d}^{9} 6 \mathrm{~s} 6 \mathrm{p}\left[14^{\circ}\right]_{7 / 2}$ & 2331.2 & 0.24 & 0.05 & & & \\
\hline & $5 \mathrm{~d}^{9} 6 \mathrm{~s} 6 \mathrm{p}\left[15^{\circ}\right]_{3 / 2}$ & 2360.2 & 2.14 & 0.27 & & & \\
\hline & $5 d^{9} 6 s 6 \mathrm{p}\left[18^{\circ}\right]_{5 / 2}$ & 2638.5 & 0.0044 & 0.00046 & & & \\
\hline & $5 \mathrm{~d}^{9} 6 \mathrm{~s} 6 \mathrm{p}\left[19^{\circ}\right]_{3 / 2}$ & 2733.9 & 1.1 & 0.18 & & & \\
\hline & $5 \mathrm{~d}^{9} 6 \mathrm{~s} 6 \mathrm{p}\left[20^{\circ}\right]_{7 / 2}$ & 2737.6 & 0.21 & 0.018 & & & \\
\hline & $5 d^{9} 6 s 6 p\left[21^{\circ}\right]_{5 / 2}$ & 2923.7 & 0.00069 & 0.00009 & & & \\
\hline & $5 \mathrm{~d}^{9} 6 \mathrm{~s} 6 \mathrm{p}\left[22^{\circ}\right]_{3 / 2}$ & 2979.1 & 3.53 & 0.70 & $\begin{array}{l}1.30^{\mathrm{c}} \\
1.10^{\mathrm{c}}\end{array}$ & & \\
\hline & ${ }^{*} 5 d^{9} 6 \mathrm{~s} 6 \mathrm{p}\left[\left.23^{\circ}\right|_{5 / 2}\right.$ & 3129.0 & 0.046 & 0.0067 & $\begin{array}{l}0.0069^{c} \\
0.0026^{c}\end{array}$ & & \\
\hline & ${ }^{*} 5 d^{9} 6 \mathrm{~s} 6 \mathrm{p}\left[24^{\circ} \mathrm{l}_{7 / 2}\right.$ & 3366.6 & 0.64 & 0.081 & $\begin{array}{l}0.10^{c} \\
0.083^{c}\end{array}$ & & \\
\hline & $5 d^{9} 6 s 6 p\left[26^{\circ}\right]_{5 / 2}$ & 5324.4 & 0.00053 & 0.00022 & & & \\
\hline & $5 \mathrm{~d}^{9} 6 \mathrm{~s} 6 \mathrm{p}\left[27^{\circ}\right]_{3 / 2}$ & 6307.3 & 0.00053 & 0.00047 & & & \\
\hline
\end{tabular}

a Moore [17].

b Migdalek [11].

c Safronova [13]

d Ansbacher [16].

e Pinnington [15]

\& Migdalek [10].

${ }^{*}\left[16^{\circ}\right],\left[22^{\circ}\right]$ must be designed as $5 \mathrm{~d}^{10} 7 \mathrm{p}{ }^{2} \mathrm{P}_{1 / 2,3 / 2} ;\left[23^{\circ}\right],\left[24^{\circ}\right]$ must be designed as $5 \mathrm{~d}^{10} 5 \mathrm{f}^{2} \mathrm{~F}_{5 / 2,7 / 2}$; see Table 1 . 
Table 6

Oscillator strengths and transition probabilities of spectral lines arising from $5 \mathrm{~d}^{10} 5 \mathrm{~g}$ and $5 \mathrm{~d}^{10} \mathrm{nh}$ configurations and radiative lifetimes of Pb IV. See page 40 for Explanation of Tables.

\begin{tabular}{|c|c|c|c|c|c|c|c|}
\hline \multicolumn{2}{|c|}{ Transition Levels ${ }^{\mathrm{a}}$} & \multirow[b]{2}{*}{ Wavelength $\lambda(\AA)^{\mathrm{a}}$} & \multirow[b]{2}{*}{ Transition Probabilities $\left(10^{8} \mathrm{~s}^{-1}\right)$} & \multicolumn{2}{|l|}{ f-Values } & \multicolumn{2}{|c|}{ Lifetimes (ns) } \\
\hline Upper & Lower & & & This work & Others & This work & Others \\
\hline \multirow[t]{5}{*}{$5 \mathrm{~g}^{2} \mathrm{G}_{9 / 2}$} & $5 \mathrm{~d}^{9} 6 \mathrm{~s} 6 \mathrm{p}\left[2^{\circ}\right]_{7 / 2}$ & 1022.2 & 0.0038 & 0.00007 & & 0.80 & $\begin{array}{l}0.88 \pm 0.15^{\mathrm{e}} \\
0.75 \pm 0.05^{\mathrm{e}}\end{array}$ \\
\hline & $5 \mathrm{~d}^{9} 6 \mathrm{~s} 6 \mathrm{p}\left[8^{\circ}\right]_{7 / 2}$ & 1304.8 & 0.081 & 0.0026 & & & \\
\hline & $5 d^{9} 6 s 6 p\left[14^{\circ}\right]_{7 / 2}$ & 1613.6 & 1.7 & 0.083 & & & \\
\hline & $5 \mathrm{~d}^{9} 6 \mathrm{~s} 6 \mathrm{p}\left[20^{\circ}\right]_{7 / 2}$ & 1798.4 & 2.2 & 0.13 & & & \\
\hline & ${ }^{*} 5 \mathrm{~d}^{9} 6 \mathrm{~s} 6 \mathrm{p}\left[24^{\circ}\right]_{7 / 2}$ & 2050.0 & 8.5 & 0.67 & & & \\
\hline \multirow[t]{12}{*}{$5 \mathrm{~g}^{2} \mathrm{G}_{7 / 2}$} & $5 \mathrm{~d}^{9} 6 \mathrm{~s} 6 \mathrm{p}\left[1^{\circ}\right]_{5 / 2}$ & 960.3 & 0.0018 & 0.00003 & & 0.75 & $\begin{array}{l}0.90 \pm 0.15^{\mathrm{e}} \\
0.90 \pm 0.07^{\mathrm{e}}\end{array}$ \\
\hline & $5 d^{9} 6 s 6 p\left[3^{\circ}\right]_{5 / 2}$ & 1028.3 & 0.094 & 0.0020 & & & \\
\hline & $5 \mathrm{~d}^{9} 6 \mathrm{~s} 6 \mathrm{p}\left[7^{\circ}\right]_{5 / 2}$ & 1303.4 & 0.23 & 0.0078 & & & \\
\hline & $5 \mathrm{~d}^{9} 6 \mathrm{~s} 6 \mathrm{p}\left[8^{\circ}\right]_{7 / 2}$ & 1304.7 & 0.0029 & 0.00007 & & & \\
\hline & $5 d^{9} 6 s 6 p\left[11^{\circ}\right]_{5 / 2}$ & 1361.0 & 0.16 & 0.0059 & & & \\
\hline & $5 d^{9} 6 s 6 \mathrm{p}\left[14^{\circ}\right]_{7 / 2}$ & 1613.6 & 0.061 & 0.0024 & & & \\
\hline & $5 \mathrm{~d}^{9} 6 \mathrm{~s} 6 \mathrm{p}\left[18^{\circ}\right]_{7 / 2}$ & 1755.0 & 0.19 & 0.0088 & & & \\
\hline & $5 \mathrm{~d}^{9} 6 \mathrm{~s} 6 \mathrm{p}\left[20^{\circ}\right]_{7 / 2}$ & 1798.4 & 0.079 & 0.0038 & & & \\
\hline & $5 d^{9} 6 \mathrm{~s} 6 \mathrm{p}\left[21^{\circ}\right]_{5 / 2}$ & 1876.8 & 0.050 & 0.0035 & & & \\
\hline & ${ }^{*} 5 \mathrm{~d}^{9} 6 \mathrm{~s} 6 \mathrm{p}\left[23^{\circ}\right]_{5 / 2}$ & 1959.4 & 11.1 & 0.85 & & & \\
\hline & ${ }^{*} 5 \mathrm{~d}^{9} 6 \mathrm{~s} 6 \mathrm{p}\left[24^{\circ}\right]_{7 / 2}$ & 2049.9 & 0.30 & 0.019 & & & \\
\hline & $5 d^{9} 6 \mathrm{~s} 6 \mathrm{p}\left[26^{\circ}\right]_{5 / 2}$ & 2641.3 & 0.23 & 0.032 & & & \\
\hline \multirow[t]{2}{*}{$6 h{ }^{2} \mathrm{H}_{9 / 2}$} & $5 \mathrm{~g}^{2} \mathrm{G}_{9 / 2}$ & 4535.7 & 0.093 & 0.029 & & 2.38 & $3.3 \pm 0.3^{e}$ \\
\hline & $5 g^{2} G_{7 / 2}$ & 4536.2 & 4.1 & 1.58 & & & \\
\hline $6 \mathrm{~h}^{2} \mathrm{H}_{11 / 2}$ & $5{ }^{2} G_{9 / 2}$ & 4535.8 & 4.2 & 1.55 & & 2.38 & $3.3 \pm 0.3^{\mathrm{e}}$ \\
\hline \multirow[t]{2}{*}{$7 \mathrm{~h}{ }^{2} \mathrm{H}_{9 / 2}$} & $5 g^{2} G_{9 / 2}$ & 2855.1 & 0.0289 & 0.0035 & & 7.52 & \\
\hline & $5 \mathrm{~g}^{2} \mathrm{G}_{7 / 2}$ & 2855.5 & 1.3 & 0.20 & & & \\
\hline $7 \mathrm{~h}^{2} \mathrm{H}_{11 / 2}$ & $5 g^{2} \mathrm{G}_{9 / 2}$ & 2855.1 & 1.3 & 0.19 & & 7.69 & \\
\hline \multirow[t]{2}{*}{$8 \mathrm{~h}^{2} \mathrm{H}_{9 / 2}$} & $5 g^{2} \mathrm{G}_{9 / 2}$ & 2301.8 & 0.013 & 0.0010 & & 17.15 & \\
\hline & $5 \mathrm{~g}^{2} \mathrm{G}_{7 / 2}$ & 2301.9 & 0.57 & 0.057 & & & \\
\hline $8 \mathrm{~h}^{2} \mathrm{H}_{11 / 2}$ & $5 g^{2} \mathrm{G}_{9 / 2}$ & 2301.8 & 0.58 & 0.055 & & 17.24 & \\
\hline
\end{tabular}

a Moore [17]

e Pinnington [15]

* $\left[16^{\circ}\right],\left[22^{\circ}\right]$ must be designed as $5 \mathrm{~d}^{10} 7 \mathrm{p}^{2} \mathrm{P}_{1 / 2,3 / 2} ;\left[23^{\circ}\right],\left[24^{\circ}\right]$ must be designed as $5 \mathrm{~d}^{10} 5 \mathrm{f}^{2} \mathrm{~F}_{5 / 2,7 / 2}$; see Table 1. 


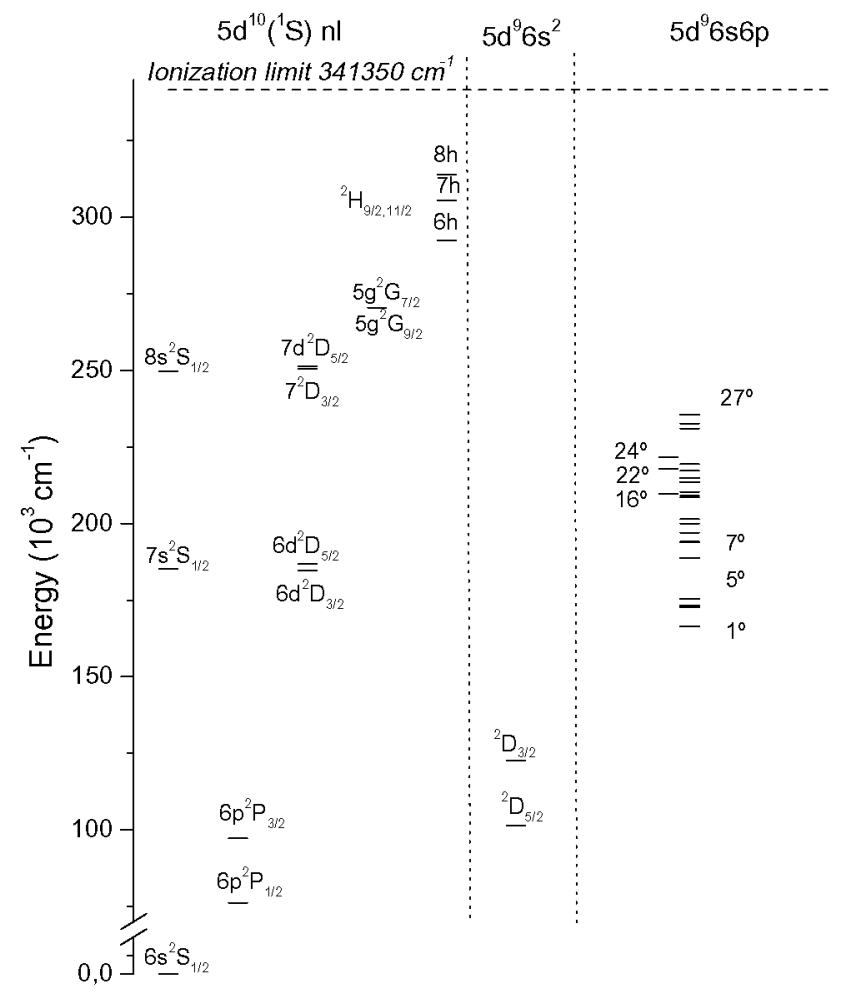

Graph 1. Energy level diagram of $\mathrm{Pb}$ IV. 